\section{Godt om samfunn og psykisk helse}

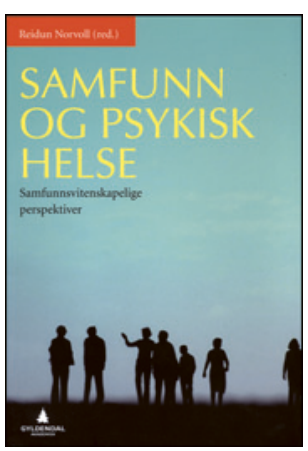

Reidun Norvoll, red.

Samfunn og psykisk helse

Samfunnsvitenskapelige perspektiver.

384 s, ill. Oslo: Gyldendal Akademisk, 2013

Pris NOK 445

ISBN 978-82-05-40913-2

Denne antologien er en videreføring av Samfunn og psykiske lidelser. Samfunnsvitenskapelige perspektiver - en introduksjon, som utkom i 2002. Målgruppen er ikke nærmere definert, men boken gir nyttige perspektiver for alle som jobber i psykisk helsevern.

Del 1 er en innføring i ulike samfunnsvitenskapelige perspektiver på psykisk helse, og forfatterne presenterer de mest relevante teoriene. De drøfter også sentrale temaer som makt og kontroll. I del 2 tar forfatterne for seg ulike aspekter ved sosial inklusjon, levekår og velferdspolitikk. I del 3 setter de søkelyset på styring, organisering og brukerbevegelse. Til sammen er det 12 kapitler. I tillegg finnes en meget omfattende litteraturliste. Boken er grundig, nyansert og gir et solid inntrykk. Den er godt skrevet og ganske lett å lese.

Forfatterne retter søkelyset mot og drøfter kunnskapsgrunnlaget for tenkning innenfor behandlingsapparatet, styringssystemene og politikken. Intensjonen er å bidra til «et utvidet syn på mennesket og behandlingen i det psykiske helsevesen og å øke bevisstheten rundt ens eget kunnskapsgrunnlag og ens egen praksis».

Selv om jeg som psykiater forsøker å bruke et bio-psyko-sosiokulturelt perspektiv i min tilnærming til mine pasienter, ble jeg utfordret i mitt tenkesett gjennom den brede omtalen av aktuell samfunnsvitenskapelig teori og forskning.

Brukernes stemme står sentralt. Forfatterne tar et historisk tilbakeblikk på en «sosial bevegelse blant mennesker med psykiske lidelser», drøfter ulike perspektiver på brukermedvirkningspolitikk og brukermedvirkning som ny styrings- og maktform. De presenterer mye forskning med utgangspunkt i pasientopplevelser: De viktige møtene, sett fra pasientene, er ikke alltid det behandlerne beskriver som de «gylne øyeblikk». Dette er tankevekkende lesing.

Viktigheten av å være i arbeid får en grundig omtale og knyttes til bedringsperspektivet og forskningen relatert til dette. Vi blir påminnet om at hjelpeapparatet og samfunnet er kommet til kort $\mathrm{i}$ å få pasienter med psykiske lidelser ut i det alminnelige arbeidslivet. I kapitlet om bruk av tvang i psykiske helsetjenester gir man en uvanlig bred og god fremstilling av feltet - ikke uten utfordringer for praktikere og ledere. Tidligere hadde vi et fagområde som het sosialpsykiatri. Boken er en påminnelse om perspektivene der psykisk helse og samfunn knyttes sammen.

Når temaet psykiatri og samfunn tas opp i internundervisningen, har jeg tenkt å anbefale kapitler fra denne teksten for våre leger i spesialisering i psykiatri. Debatt kan det også bli ...

Tordis Sørensen Høifødt

Allmennpsykiatrisk klinikk

Universitetssykehuset Nord-Norge

\section{Grunnleggende og praktisk om svimmelhet og dårlig balanse}

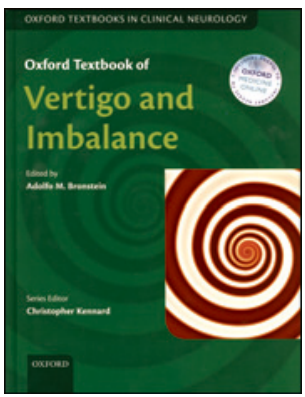

Adolfo Bronstein, red.

0xford textbook of vertigo and imbalance

354 s, tab, ill. Oxford: Oxford University Press, 2013. Pris GBP 115

ISBN 978-0-19-960899-7

Vi blir stadig mer bevisst om tilstedeværelse av lyd eller stillhet formidlet via cochlea, men vi har ikke noen bevissthet om funksjonen av vestibularisapparatet $i$ det indre øret og dets forbindelser med sentralnervesystemet - inntil noe går galt.

Med utgangspunkt i vestibularisapparatets biofysikk og fysiologi fører forfatterne oss gjennom et mangfold av kliniske symptomer og funn knyttet til svimmelhet og problemer med balansen. De har lagt vekt på en praktisk tilnærming ved anamnese og undersøkelser. Svimmelhet er en subjektiv opplevelse som det kan være vanskelig for pasienten å formidle til andre. Legen må legge stor vekt på å tolke og stille avklarende spørsmål til pasienten. Boken gir veiledning i hvordan dette kan gjøres

Svimmelhet berører en rekke spesialiteter. Forfatterne har lagt vekt på nødvendig tverrfaglig samarbeid og forståelse som bør komme pasientene til gode. Her finnes interessante kapitler om hva øre-nese-hals-legen bør vite om nevrologiske sykdommer som gir svimmelhet, respektive hva nevrologen bør vite om øre-nese-halssykdommer.

De 30 kapitlene er skrevet av 50 forfattere fra ti land - under stram redaksjon. Forfatterne er i hovedsak de samme som i løpet av de siste 10-20 årene ved sine originalpublikasjoner har utvidet og fornyet vår forståelse av svimmelhet. Det blir gjort rede for foreløpige resultater i arbeidet med å utarbeide en internasjonal klassifisering av vestibulære sykdommer.

Forfatterne har gått særlig grundig gjennom vestibulookulære reflekser og bruk av mangfoldet av vestibulær nystagmus i praktisk diagnostikk. Tiden da kalorisk prøve var enerådende funksjonstest av vestibularisapparatet er over. Her finnes gode beskrivelser av tilstander i hjernestamme og lillehjerne som gir svimmelhet, og som krever årvåkenhet i det daglige arbeidet med pasienter som er svimle. Til slutt er det gjort rede for at man etter avansert nevrootologisk diagnostikk står igjen med ca. $25 \%$ av pasientene uten patologiske funn, hvor atferdsforstyrrelser, spesielt angst og panikklidelser, er årsak til svimmelheten.

Teksten har stor detaljrikdom som utfylles og systematiseres i gode tabeller og figurer. Referansene etter hvert kapittel er omfattende og godt oppdatert. Stikkordregisteret fungerer bra. Når man kjøper boken, får man også tilgang til en nettutgave. Her finnes en del supplerende videoer som viser undersøkelsesmetoder, men det er beklagelig at det ikke presenteres eksempler på patologiske funn i større grad.

I Norge har interessen for svimmelhet vært økende. Mange ulike profesjoner har gjort seg gjeldende på det diagnostiske og terapeutiske området. Dette er boken for alle som vil ha omfattende og allsidig kunnskap om svimmelhet.

Hans H. Elverland

$\emptyset$ re-nese-halsseksjonen

Nordlandssykehuset Lofoten 